\title{
APPLICATION OF MULTICRITERIA OPTIMIZACION METHODS IN THE DESIGN OF ROAD EMBANKMENTS
}

\author{
Nazim Manić, Izet Hot, Dragan Lukić, Mladen Pantić
}

Original scientific paper

In the design of roads, embankments stand out as the most sensitive elements of design in terms of cost-effectiveness, safety and comfort, and are influenced by numerous factors: subsoil fill, embankment material, groundwater level, proximity of earthquake faults, etc. Cost-effectiveness on the one hand, and safety and comfort on the other, are always in conflict. A solution should therefore be sought to somehow satisfy all the demands placed during the design stage. The subject of this paper is to find the best (optimal) solution in the design of embankments. Criteria for the design of road embankments have been analysed and optimized. The results of embankment design optimization are shown taking into account criteria for determining the optimal solution (economic criteria, safety criteria, traffic criteria, geological and hydro-geological criteria). Research results are presented analytically and graphically.

Keywords: embankment; optimization criteria; roads

Primjena metoda višekriterijske optimizacije kod projektiranja nasipa prometnica

Izvorni znanstveni članak

Tokom projektiranja saobraćajnica, izdvajaju se nasipi kao najosjetljiviji dio sa aspekta obezbjeđivanja ekonomičnosti, sigurnosti i udobnosti, a na to utiču mnogi faktori: temeljno tlo nasipa, materijal od kojega se gradi nasip, visina podzemne vode, blizina rasjeda pri zemljotresu i dr. Ekonomičnost s jedne strane, i sigurnost i udobnost s druge strane, uvijek su u koliziji. Zbog toga je potrebno tražiti rješenje koje će na neki način zadovoljiti sve zahtjeve koji se postavljaju tokom projektiranja. Predmet istraživanja ovog članka je iznalaženje najboljeg (optimalnog) rješenja tokom projektiranja nasipa. Analizirani su kriteriji projektiranja nasipa prometnica i izvršena je njihova optimizacija. Prikazani su rezultati optimizacije nasipa, uzimajući u obzir kriterije za određivanje optimalnog rješenja (ekonomski kriteriji, kriteriji sigurnosti, prometni kriteriji, geološki te hidrogeološki kriteriji). Rezultati istraživanja su prikazani analitički i grafički.

Ključne riječi: kriteriji optimizacije; nasipi; prometnice

\section{Introduction}

Design of roads is a complex research process that considers a large number of parameters in order to find an optimal solution. This includes analysis of these parameters and application of appropriate methods, [1]

The aim of a modern road network is to enable fast, safe, comfortable and cost-effective transportation of people and goods. The embankment is one of the road elements that requires application of high standards in the design stage, because roads are expected to offer maximum quality and minimum maintenance costs during their operation, [2]. In order to ensure that these requirements are met, this paper analyses construction of embankments, including the stages of research, design, construction and operation. With that in mind, it is necessary to optimize the most important elements that affect the construction of embankments, from initial research to final operation. In addition, the embankment is the part of a road that sustains the most damage in normal conditions, and in particular in circumstances of natural disasters (heavy rainfall or snowfall, floods and earthquakes). In order to avert damage to embankments or to minimize it, special attention should be paid to the stability of embankments due to effects of natural disasters.

Optimal construction of an embankment may have a significant impact on vertical geometry of the road, by increasing or decreasing the number of vertical curves, which in turn reduces or increases the required investment.

In determining the optimal solution, it is necessary to analyse specific objectives and criteria. Doing so, it is necessary to prioritize certain criteria and to provide numerical indicators for each criterion. In the process of determining optimal solutions in the design of road embankments by using multi-criteria analysis, the following sets of criteria are considered:

- economic criteria,

- $\quad$ stability criteria,

- traffic criteria,

- geological and hydro-geological criteria.

It is necessary to establish a hierarchy of these criteria and, based on this, to determine the method of multicriteria optimization in order to obtain an optimal solution.

\section{Theoretical basis}

The basis for solving the task of determining an optimal solution for the height of road embankments is related to the following two fields:

- theory of multi-criteria optimization, and

- design criteria for road embankments.

\subsection{Theoretical basis of multi-criteria optimization}

The problem of multi-criteria optimization is formulated as follows:

$\max _{x \in X} F(x)$

In multi-criteria optimization, the important role is that of the decision-maker. The main role of the decisionmaker is to define the criteria and the preference structure 
as well as to decide on the final solution. Other multicriteria optimization phases are implemented on a technical level at which a system analyst, in consultation with the decision-maker, prepares information necessary for the phase in which final decision is made [3].

For making the final decision, one of the following procedures may be implemented: consultation, assessment and ranking of variant solutions, and voting. With respect to determining an optimal design solution for road embankments, the following methods are most commonly used: Method of weights and PROMETHEE method.

\subsubsection{Method of weight coefficients}

The method of weights coefficients is one of the methods in which the decision-maker has the option to actively participate in problem solving. This method is specific in that the decision-maker has to assign weight to each criterion. In this way, the decision-maker expresses his preferences and determines the importance of each criterion in relation to the problem being solved.

This method resolves the problem of maximizing the vector criterion function:

$$
\max _{x \in X}\left(f_{1}(x), f_{2}(x), \ldots, f_{m}(x)\right)
$$

Through consistent application of the assessment ranking of each indicator and criterion, taking into account the weight matrix, the aggregate value of the adequacy of each variant can be expressed as follows:

$$
\max _{x \in X} \sum_{i=1}^{n} w_{i} f_{i}(x) ; w_{i} \geq 0
$$

This method is particularly suitable when the criteria are of the same or similar nature. The decision maker should assign to each criterion an appropriate weight or weight coefficient $w_{i}, i=1, \ldots, m$. The weight coefficients should be non-negative numbers, but not all of them can simultaneously be equal to zero, and

$$
\sum_{i=1}^{n} w_{i}=1
$$

In practical problems, objective functions are often expressed in different units of measurements, so weights $w_{i}$ would be unnamed quantities if the objective function fi were not normalized.

\subsubsection{PROMETHEE method}

The PROMETHEE method (Preference Ranking Organization Method for Enrichment Evaluation) is one of the most recent methods in the field of multi-criteria analysis, which was created in 1982 and was further expanded in 1984 [4].

A multi-criteria problem may be shown analytically and in tabular form:

$$
\max \left\{\left(f_{1}\left(a_{j}\right), f_{2}\left(a_{j}\right), \ldots, f_{n}\left(a_{j}\right)\right) \mid a_{j} \in A\right\}
$$

The PROMETHEE method introduces a preference function $P(a, b)$ for alternatives $a$ and $b$, which are evaluated by criterion functions (we will designate one of them with an $f$ ) (Tab. 1).

Table 1 Tabular display of variants and criteria [1]

\begin{tabular}{|c|c|}
\hline & $f_{1}(),. f_{2}(),. \ldots, f_{i}(),. \ldots, f_{m}()$. \\
\hline$a_{1}$ & \\
$a_{2}$ & $f_{i}\left(a_{i}\right)$ \\
$\ldots$ & \\
$a_{i}$ & \\
$\ldots$ & \\
$a_{n}$ & \\
\hline
\end{tabular}

The alternative $\mathrm{a}$ is better than alternative $\mathrm{b}$ according to the criterion $f$ if $f(a)>f(b)$ and the preference function is defined as follows

$$
P(a, b)=\left\{\begin{array}{cl}
1, & \text { if } f(a) \leq f(b) \\
P(f(a)-f(b)), & \text { if } f(a)>f(b)
\end{array}\right\}
$$

expressing the intensity of preference for the alternative $a$ in relation to the alternative $b$.

The preference function assigned to a particular criterion is a function of the difference of criteria values of the alternatives, and can be written as follows:

$$
P(a, b)=P(f(a)-f(b))=P(d)
$$

The preference index is determined by the following expression:

$$
\Pi(a, b)=\frac{\sum_{i=1}^{n} w_{i} P_{i}(a, b)}{\sum_{i=1}^{m} w_{i}}
$$

Applying the PROMETHEE I method based on the given conditions, a positive preference flow $\left(\Phi^{+}\right)$and a negative preference flow $\left(\Phi^{-}\right)$are computed, which serve to arrive at a partial order of the compared alternatives:

$$
\Phi^{+}(a)=\sum_{x \in K} \Pi(a, x), \Phi^{-}(a)=\sum_{x \in K} \Pi(a, x) .
$$

The PROMETHEE II method determines the complete order of the compared alternatives based on the net preference flow:

$$
\Phi=\Phi^{+}-\Phi^{-}
$$

The best variant is the one with the largest $\Phi$ value.

\subsection{Design criteria for road embankments}

By evaluating different variant solutions, the most important criteria and their inter-relations are analysed in order to obtain the most optimal solution. In this paper, we have analysed the following design criteria for road embankments. 


\subsubsection{Economic criteria}

Economic criteria include the analysis of the price of construction and the price of operation, as the dominant factors for analysis.

The costs of embankment construction have two main elements: the costs that can be measured with money and the costs that cannot be measured with money, [2].

The costs that can be evaluated in terms of money may be grouped as follows:

- embankment costs (construction costs, operating costs).

- the cost of road users (vehicle operating costs, vehicle maintenance costs, costs of traffic accidents, costs related to the length of travel).

The costs that cannot be evaluated in terms of money may be grouped as follows:

- recommendations of road users (comfort and convenience);

- $\quad$ social and economic factors (recreation, social and cultural growth)

The total price of an embankment may be expressed as follows:

$$
C_{u}=C_{Z}+C_{I}+C_{E} \quad \text { (euro) }
$$

\subsubsection{Stability criteria}

Stability criteria include: slope stability, seismic stability and embankment settlement.

\subsubsection{Slope stability}

Slope stability depends on the sheer stresses of the slip surface $[5,7]$.

The ratio of shear strength and shear stress is the safety coefficient $\left(F_{s}\right) . F_{s}$, as the primary indicator of safety or stability in the underlying geo-technical facilities, with the help of Bishop method, which may be expressed as follows [7]:

$$
\begin{gathered}
F_{s}=\frac{\sum \frac{\left(c^{\prime} b_{i}+\left(W_{i}-u_{i} b_{i}\right)\right) \tan \phi^{\prime}}{m_{\alpha}}}{\sum W_{i} \sin \alpha_{i}} \\
m_{\alpha}=\cos \alpha_{i}\left(1+\frac{\tan \alpha_{i} \tan \phi^{\prime}}{F_{s}}\right)
\end{gathered}
$$

Bishop method for slope stability, with the help of iteration calculates $F_{s}$, one of the best known and most widely used method for calculating $F_{s}$.

\subsubsection{Seismic stability}

During seismic activity, there occurs a certain change in the pore water pressure $(u)$ due to additional pore pressure resulting from the effects of dynamic loading, which is expressed by expression $[3,5]$ :

$$
u_{d}=0,6 \cdot a_{p} \cdot \operatorname{ctan} \varphi \cdot \log N
$$

$$
\begin{aligned}
& u_{k}=u_{p}+u_{d} \\
& a_{p}=0,0159 \cdot e \cdot 0,868 M(R+0,0606 \cdot e \cdot 0,7 M)-1,09
\end{aligned}
$$

When the above value is inserted in Eq. (12), safety coefficient during seismic activity is $[3,5]$ :

$$
F_{s}=\frac{\sum \frac{\left(c^{\prime} b_{i}+\left(W_{i}-u_{k} b_{i}\right)\right) \tan \phi^{\prime}}{m_{\alpha}}}{\sum W_{i} \sin \alpha_{i}+\sum a_{p} W_{i}} .
$$

\subsubsection{Embankment load and settlement}

Settlement of soil surface or foundation is a soil deformation resulting from a change (increase) in the vertical stress in the soil. Settlement is inevitable, but in compressible soil it may be permitted if it does not affect the functionality and stability of the embankment.

Most methods for calculating estimated settlement are based on the calculation of the settlement of a part of the layer of finite thickness $h_{i}$ :

$$
S=\sum \Delta s=\frac{\Delta \sigma_{v}}{M_{s}} h, \quad \Delta s=\frac{\Delta \sigma_{v}}{M_{s}} h_{i}
$$

\subsubsection{Traffic criteria}

The effects of traffic criteria are taken deterministically and concern primarily the effects of traffic density and computed rate. For the purposes of analysing the traffic conditions on a road network, three basic parameters of traffic flow have the most important roles: flow of vehicles, flow density and flow rate.

\subsubsection{Geological and hydro-geological criteria}

Geological and hydro-geological conditions are the conditions that determine the type of material and the state of water in them. These conditions are analysed from the point of construction, as they have a dominant impact in the construction stage; the analysis covers materials in embankments and the impact of frost and water.

\subsubsection{Construction materials for road embankments}

The quality of materials for embankment construction includes the following: determining the liquid limit; determining the degree of unevenness of the material; determining the possible presence of organic matter in the material; determining the moisture content in the material; determining the specific gravity of the material; determining the volumetric mass density of the material; determining the granulometric composition.

\subsubsection{Construction criteria for road embankments}

In embankment construction, it is necessary to control the following: the state of subsoil on which the embankment is constructed; thickness of the individual layers and compliance with the type of material and means of compaction; transverse and longitudinal sloping 
of each layer; the technology of embankment construction on transversally sloped terrain; compressibility modulus; moisture content of the installed material.

\subsubsection{Hydro-geological criteria}

Hydrological conditions are determined based on the following: groundwater level; depth of frost penetration; frost resistance of the material, etc.

Hydrological conditions are favourable if: the ground water level remains below the depth of frost penetration; good drainage is provided; lateral flow of water into the road bed is prevented (from watercourses and surface water).

\section{Application of MCO in the design of road embankments}

Criteria and sub-criteria that are used for optimization of embankment design are shown in Tab. 2.

To ensure precise evaluation and cross-comparison of alternatives, qualitative characteristics need to be expressed in quantitative indicators. To do so, the following needs be done:

- quantification of qualitative attributes,

- $\quad$ normalization of attributes, and

definition of criteria weights.

Table 2 Table for assessing the weight of criteria and sub-criteria

\begin{tabular}{|c|c|c|c|c|}
\hline $\begin{array}{l}\text { Name of } \\
\text { Criterion }\end{array}$ & $\begin{array}{l}\text { Weight of } \\
\text { criterion }\end{array}$ & Sub-criteria & $\begin{array}{l}\text { Objective } \\
\text { function }\end{array}$ & $\begin{array}{c}\text { Weight/ } \\
\text { assessment type }\end{array}$ \\
\hline \multirow{3}{*}{ Economic Criteria } & & Costs of road construction & $\min$ & Quantitative assessment \\
\hline & & Costs of road operation & $\min$ & Quantitative assessment \\
\hline & & Soc. \& econ. factors (reg. dev., etc.) & $\max$ & Qualitative assessment \\
\hline \multirow{4}{*}{ Stability Criteria } & & Embankment stability & $\max$ & Qualitative assessment \\
\hline & & Seismic embankment stability & $\max$ & Qualitative assessment \\
\hline & & Load & $\max$ & Qualitative assessment \\
\hline & & Settlement & $\min$ & Qualitative assessment \\
\hline Traffic Criteria & & Vehicle flow & $\max$ & Quant. assessment \\
\hline \multirow{3}{*}{$\begin{array}{l}\text { Geological and Hydro- } \\
\text { Geological Criteria }\end{array}$} & & Material & $\max$ & Qualitative assessment \\
\hline & & Foundation cond. & $\max$ & Qualitative assessment \\
\hline & & Hydro-geological cond. & $\max$ & Qualitative assessment \\
\hline
\end{tabular}

\subsection{Quantification of qualitative criteria}

This paper uses a scale for quantification of qualitative attributes into quantitative ones, defined on an interval $\{9,1 / 9\}$ and based on a basic Saaty scale [6]. Saaty has formulated a scale of 5 (five) values and four (4) intermediate value, where the value of nine (9) is the upper limit and the value of one (1) is the lower limit of the interval (the set of values $\{1,1 / 9\}$ is reciprocal to the interval $\{9,1\}$ where the value of nine (9) is the lower and the value of one (1) is the upper limit).

Table 3 Quantification of qualitative values

\begin{tabular}{|c|c|c|c|c|c|c|}
\hline $\begin{array}{c}\text { Qualitative } \\
\text { assessment }\end{array}$ & Poor & Low & Average & High & $\begin{array}{c}\text { Very } \\
\text { high }\end{array}$ & $\begin{array}{c}\text { Criterion } \\
\text { objective }\end{array}$ \\
\hline Quantitative & 1 & 3 & 5 & 7 & 9 & Max \\
\cline { 2 - 7 } assessment & 9 & 7 & 5 & 3 & 1 & Min \\
\hline
\end{tabular}

\subsection{Vector normalization}

Normalized value $n_{i j}$, i.e. the normalized decision matrix $N$, is obtained from the equation:

$$
\begin{aligned}
& \text { Norm } a_{j}=\sqrt{\sum_{i=1}^{m} f_{i j}^{2}} \\
& n_{i j}=\frac{f_{i j}}{N o r m a_{j}}=\frac{f_{i j}}{\left(\sum_{i=1}^{m} f_{i j}^{2}\right)^{\frac{1}{2}}} ;(\text { for max type criteria })
\end{aligned}
$$

$$
n_{i j}=1-\frac{f_{i j}}{N o r m a_{j}}=1-\frac{f_{i j}}{\left(\sum_{i=1}^{m} f_{i j}^{2}\right)^{\frac{1}{2}}} ;(\text { for } \min \text { type criteria })
$$

Such modified (quantified and normalized) decision matrix can be subjected to the aforementioned methods of multi-criteria analysis.

\subsection{Determining the relative weight}

Relative weights have been determined by considering the weight of the criteria proposed by a selected sample group of ten expert respondents.

The most common method used to determine the "weight" of each criterion is the survey method, and the most often used and most developed survey method is the Delphi method. This method includes methodologically organized use of expert knowledge in order to predict future states or phenomena. This method avoids direct discussion and confrontation of people and opinions, which render biased the classic method of obtaining a common prediction by a group of experts in an open meeting.

It is recommended to have a group of ten to fifteen experts (assessment team). Experts are contacted by means of a series of questionnaires [1]. This process is carried out in a few steps, usually four, and the final prediction is obtained as the mean value of predictions from the last series of questionnaires. 


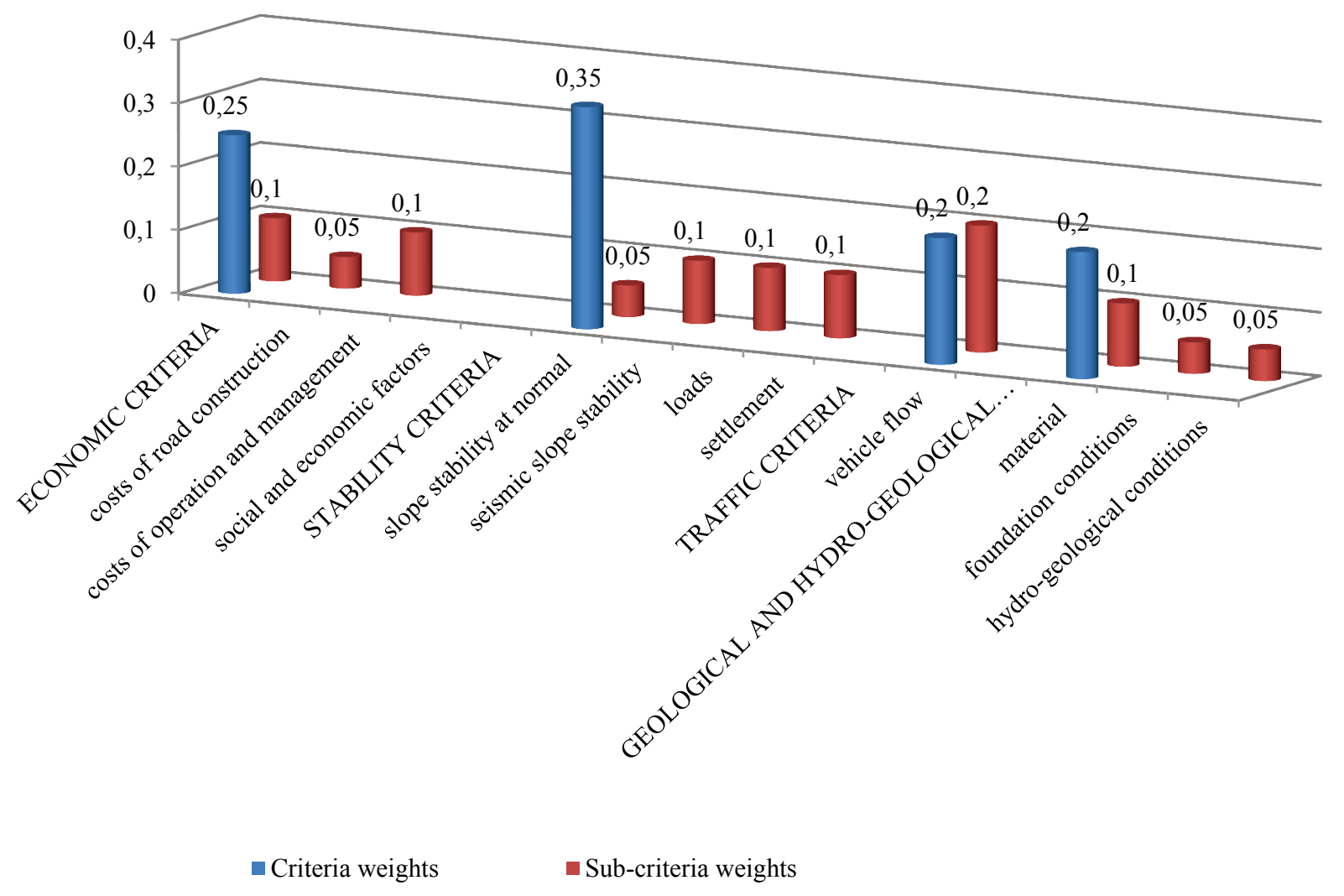

Figure 1 Diagram of the distribution of the results of criteria weighting by the assessment team

\subsection{The mathematical model of multi-criteria decision making}

The model of multi-criteria decision-making (MCDM) has the following general mathematic formula:

$$
\begin{aligned}
& \operatorname{ax}\left\{f_{1}(x), f_{2}(x), \ldots, f_{n}(X)\right\}, n \geq 2, \\
& x \in A=\left[a_{1}, a_{2}, \ldots, a_{m}\right]
\end{aligned}
$$

The known values of $f_{j i}$ for each discussed criteria $f_{i}$ were obtained with each of the possible alternatives $a_{j}$ :

$$
f_{j i}=f_{i}\left(a_{j}\right) \quad \forall(j, i) ; j=1,2, \ldots, m ; i=1,2, \ldots, n
$$

Each attribute should provide a means of assessment (evaluation) of the level of one criteria (objective). A large number of attributes should characterize each action (alternative) and they are selected based on the criteria selected by the decision-maker.

The typical method for stating an MCDM problem is in matrix form. The matrix shows criteria values for individual alternatives:

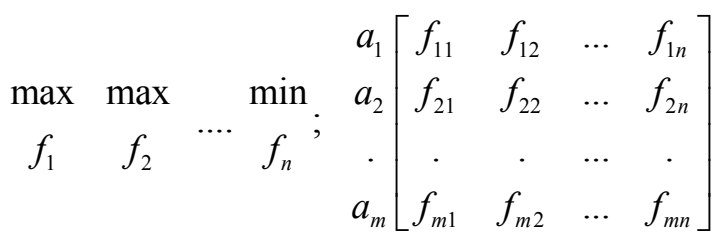

Through the described MCDM methods, the most optimal embankment is selected. The most optimal embankment is checked for compliance with the criteria used for optimization. The main output parameter of compliance with optimization criteria is $h_{\max }$, the maximum possible height of the embankment. The maximum possible height of the embankment, $h_{\max }$, will be calculated using the method proposed by Taylor, [7]:

$$
\begin{aligned}
& c_{d}=\frac{c^{\prime}}{F_{s}} ; \tan \varphi_{d}^{\prime}=\frac{\tan \varphi^{\prime}}{F_{s}}, \\
& N_{s}=\frac{c_{d}}{\gamma \times h_{\max }}=\frac{c^{\prime}}{F_{s} \gamma \times h_{\max }},
\end{aligned}
$$

and based on (25):

$$
F_{s}=\frac{c^{\prime}}{N_{s} \gamma \times h_{\max }} \Rightarrow h_{\max }=\frac{c^{\prime}}{N_{s} \gamma \times F_{s}} .
$$

\section{Numerical implementation of analysis}

For the implementation of the multicriteria optimization of embankment design we have chosen the Preliminary Design of a part of the E-863 motorway, Belgrade - South Adriatic Motorway.

Special software has been developed for the optimization of road embankment design. Several calculations were analysed, and the paper provides a detailed description of a calculation for the embankment at chain age $139+650-139+968,18$, total length $328,18 \mathrm{~m}$. 
Table 4 Decision matrix for the four variants of the embankment criteria

\begin{tabular}{|c|c|c|c|c|c|c|c|c|c|c|c|}
\hline \multicolumn{10}{|c|}{ DECISION MATRIX } \\
\hline Var. & $\mathrm{f} 1$ & $\mathrm{f} 2$ & $\mathrm{f3}$ & $\mathrm{f} 4$ & $\mathrm{f5}$ & $\mathrm{f6}$ & $\mathrm{f} 7$ & $\mathrm{f8}$ & $\mathrm{f9}$ & $\mathrm{f10}$ & $\mathrm{f} 11$ \\
\hline Var. a & 260000 & 13 & High & High & Average & Very high & Average & 15000 & Low & Poor & High \\
\hline Var. b & 310100 & 12 & Average & Poor & Low & Average & Average & 10250 & Average & Low & High \\
\hline Var. c & 458000 & 10 & Low & High & High & High & Average & 11258 & Low & Low & Average \\
\hline Var. d & 358000 & 8 & Low & Average & Average & Average & Low & 16580 & High & Very high & Low \\
\hline
\end{tabular}

Table 5 Ranking of the embankment optimization variants using weights and the PROMETHEE method

\begin{tabular}{|c|c|}
\hline \multicolumn{2}{|c|}{ weights and the PROMETHEE method } \\
\hline Ser. No. of Var. & Variant Ranking \\
\hline 1 & 4 \\
\hline 2 & 3 \\
\hline 3 & 2 \\
\hline 4 & \\
\hline
\end{tabular}

Input-output data for embankment calculation:

a) Stability check

Input data

$b=1 \mathrm{~m} ; c^{\prime}=10 \mathrm{kN} / \mathrm{m}^{2} ; M_{s}=6349 \mathrm{kN} / \mathrm{m}^{2} ; F_{s p}=1,6 ; h_{1}=0,6 \mathrm{~m}$; $h_{2}=1 \mathrm{~m} ; h_{3}=1,3 \mathrm{~m} ; h_{4}=2 \mathrm{~m} ; h_{5}=2,5 \mathrm{~m} ; h_{6}=2,9 \mathrm{~m} ; h_{7}=3 \mathrm{~m}$; $h_{8}=2,9 \mathrm{~m} ; h_{9}=2,4 \mathrm{~m} ; h_{10}=1 \mathrm{~m} ; M=7 ; N_{s}=0,06 ; R=50 \mathrm{~km}$; $\alpha_{1}=60^{\circ} ; \alpha_{2}=53^{\circ} ; \alpha_{3}=46^{\circ} ; \alpha_{4}=39^{\circ} ; \alpha_{5}=32^{\circ} ; \alpha_{6}=25^{\circ} ; \alpha_{7}=18^{\circ}$; $\alpha_{8}=11^{\circ} ; \alpha^{9}=4^{\circ} ; \alpha_{10}=-3^{\circ} ; \gamma=18 \mathrm{kN} / \mathrm{m}^{3} ; \varphi^{\prime}=20^{\circ} ; b_{1}=10$; $\gamma_{v}=9,81 \mathrm{kN} / \mathrm{m}^{3} ; h_{w 1}=0,6 \mathrm{~m} ; h_{w 2}=1 \mathrm{~m} ; h_{w 3}=1,3 \mathrm{~m} ; h_{w 4}=2 \mathrm{~m}$; $h_{w 5}=1,2 \mathrm{~m} ; h_{w 6}=0,4 \mathrm{~m} ; h_{w 7}=0 \mathrm{~m} ; h_{w 8}=0 \mathrm{~m} ; h_{w 9}=0 \mathrm{~m}$; $h_{w 10}=0 \mathrm{~m} ; q=10 \mathrm{kN} / \mathrm{m}^{2}$.
Output data - results

$h_{\text {max }}=7,15 \mathrm{~m}$; slope stability $F_{s}=1,573$; seismic stability $F_{s}=1,295$.

b) Checking of geological and hydro-geological criteria Input data

$C B R=9 \% ; d_{0,063}=12 \% ; d_{10}=0,25 \% ; d_{60}=8 \% ; d_{\max }=30$ $\mathrm{cm} ; \gamma_{\mathrm{d}}=98 \mathrm{kN} / \mathrm{m}^{3} ; \gamma_{n d}=100 \mathrm{kN} / \mathrm{m}^{3}$.

Output data - results

$D=98 \% ; u=32$.

c) Checking of economic criteria

Input data

$\Delta h_{1}=4,972 \mathrm{~m} ; \Delta h_{2}=5,5 \mathrm{~m} ; \Delta h_{3}=5,151 \mathrm{~m} ; \Delta h_{4}=4,249 \mathrm{~m}$; $\Delta h_{5}=3,744 \mathrm{~m} ; \Delta h_{6}=3,602 \mathrm{~m} ; \Delta h_{7}=3,56 \mathrm{~m} ; \mathrm{L}_{\mathrm{n}}=328,18 \mathrm{~m}$; $P_{p}=16409\left(\mathrm{~m}^{2}\right) ; N_{i}=5$ euro $/ \mathrm{m}^{3} ; N_{z}=0,5$ euro $/ \mathrm{m}^{2} ; N_{e}=14,53$ euro $/ \mathrm{m} ; \beta=32^{\circ} ; h_{\min }=1(\mathrm{~m}) ; \quad C_{\mathrm{opt}}=310000$ (euro); $S_{p}=26$ $\mathrm{m}$.

Output data - results

$C_{u}=251322,948$ euro; $h_{\min }=1 \mathrm{~m}$.

Final results of the embankment height $h_{\max }=7,268 \mathrm{~m} ; h_{s r}=4,397 ; h_{\min }=1 \mathrm{~m} ; h=5,5 \mathrm{~m}$.

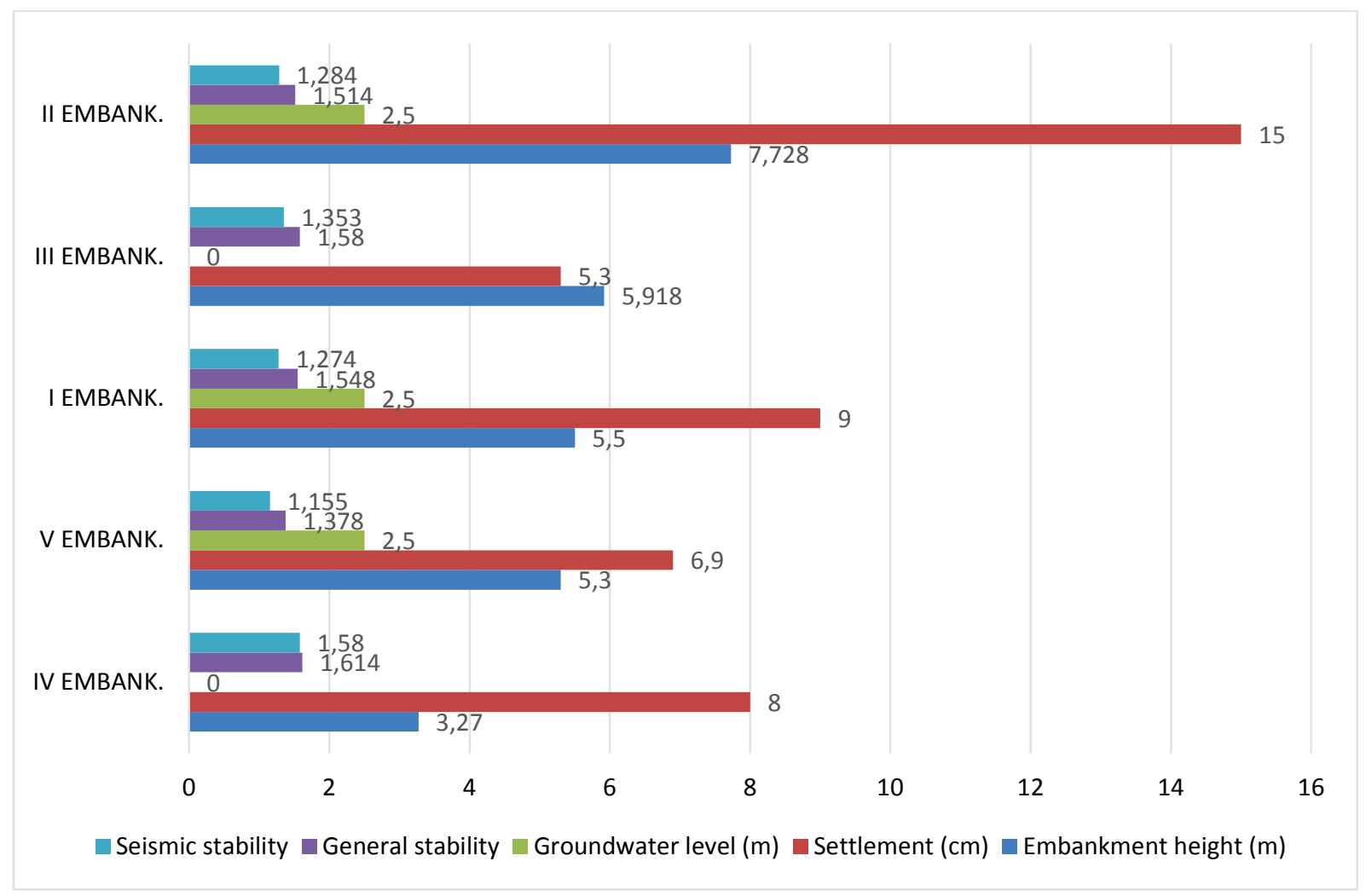

Figure 2 Graphical representation of analysed embankments

\subsection{Comparative analysis of various elements of the embankment}

By analysing the graphs, we can conclude that the level of settlement rises with the embankment height (Fig. 2). Based on Fig. 3, we can conclude that the stability of embankment slopes decreases with an increase of groundwater. Fig. 4 shows that an increase in the materials' volumetric mass density results in reduced slope stability.

Fig. 5 shows that with increasing height, slope stability decreases. With an increase in the inclination of 
embankment slope, the price of embankment construction decreases, Fig. 6. What is common to Figs. 1 through 5 is that seismic stability is always lower than the general embankment slope stability, and this warrants special attention.

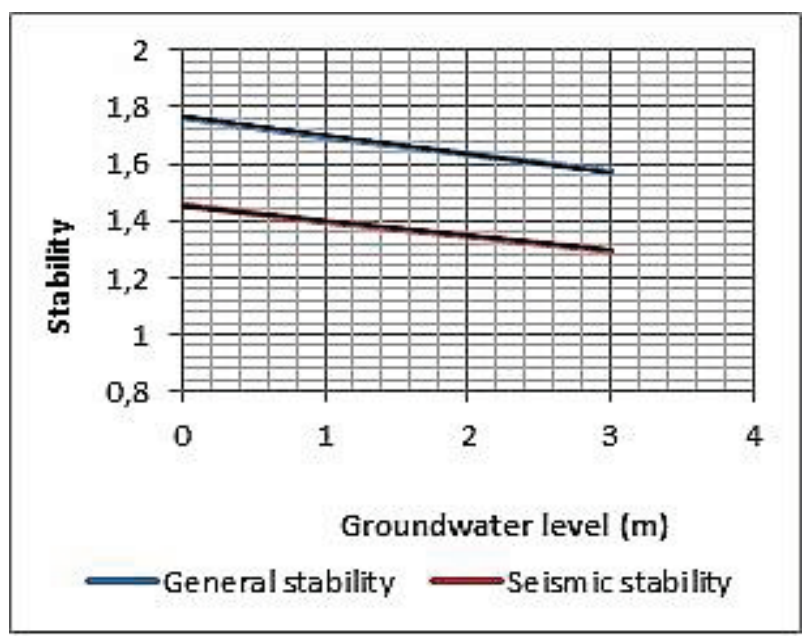

Figure 3 Impact of groundwater level on slope stability

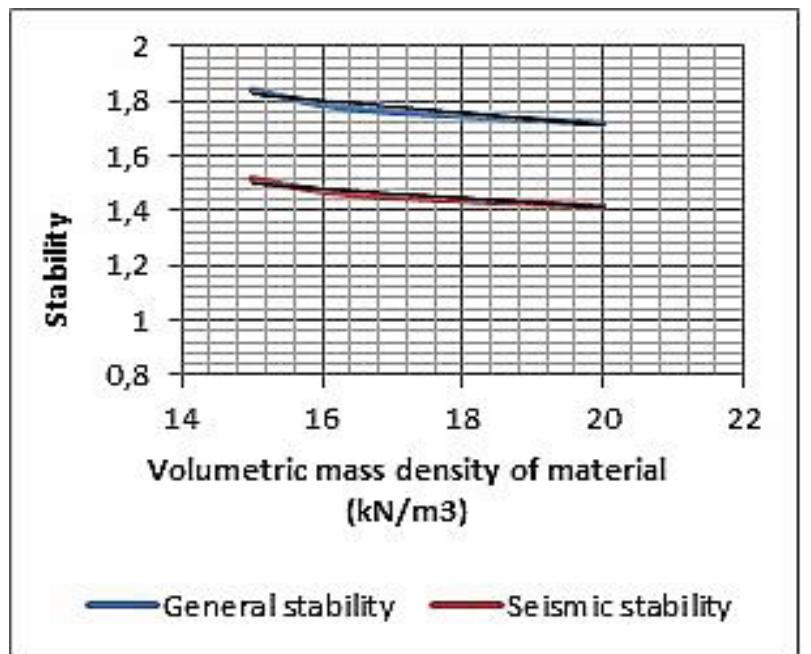

Figure 4 Impact of volumetric mass density of materials on embankment stability

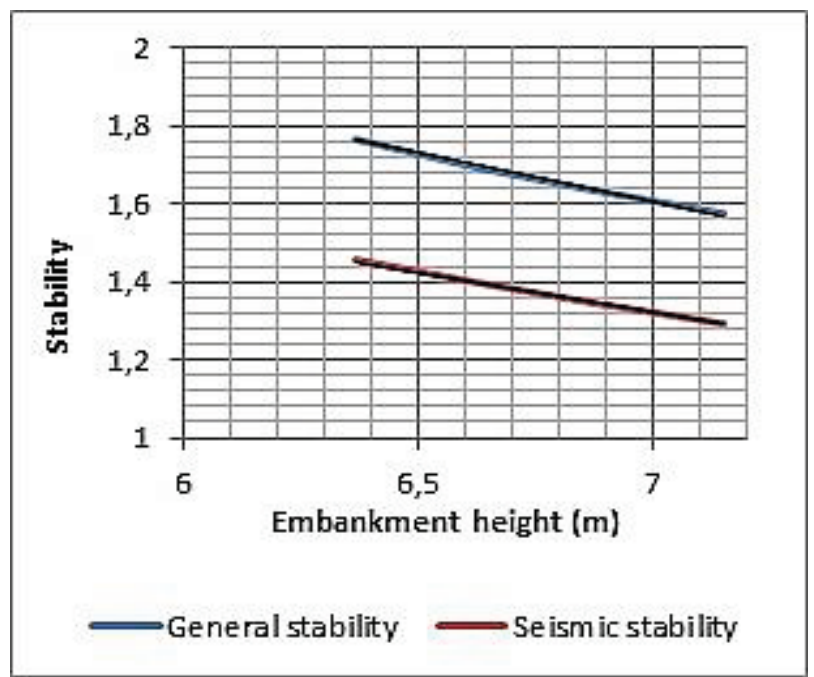

Figure 5 The ratio of embankment height - stability

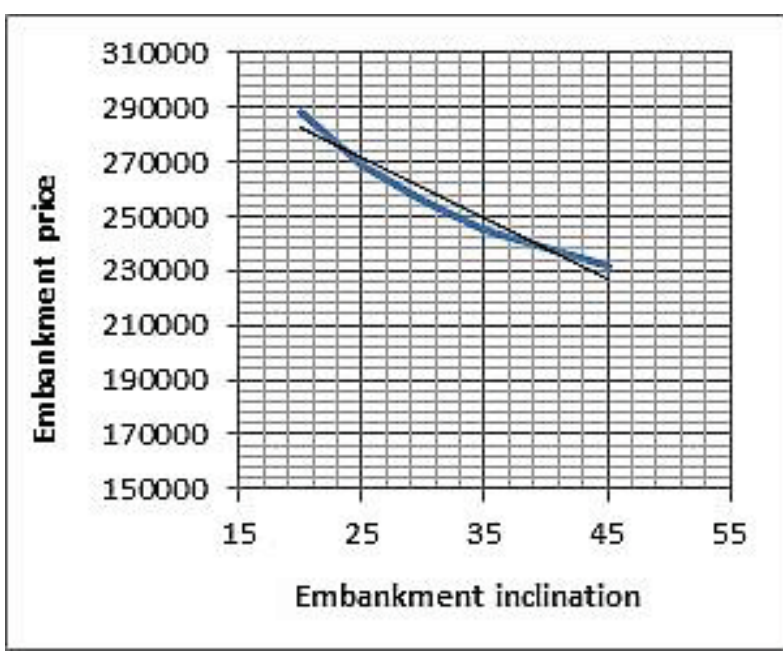

Figure 6 The ratio of embankment inclination - price of embankment

\section{Conclusion}

This paper has presented an original and new method for optimizing embankments based on economic criteria, stability criteria, and traffic, geological and hydrogeological criteria. Research results are related to the improvement of quality of embankment design. In comparison with the existing approaches to this issue, the following improvements are readily apparent:

- improved system friendliness for decision-makers and designers,

- improved user friendliness,

- significant improvement of the design approach,

- a comprehensive approach to embankment optimization based on the most important criteria.

By unifying modelling on the basis of multiple criteria, the system is adapted to the needs of both simple and complex designs. In this way, the possibility of errors in embankment designs has been reduced.

The new method of selecting and processing the elements and relations is suitable for use in the field of design, as shown in detail in the example above. The criteria which determine the elements of embankment have been selected on the basis of their promising design properties. The system is thus conceptually adjusted to the input of data, which improves comprehensiveness of the optimal solution.

\section{Symbols}

$F(x) \quad$ vector criterion function

$f_{i}(x) \quad$ individual criterion functions

$\varphi^{\prime} \quad$ internal friction angle $\left(^{\circ}\right)$

$\alpha \quad$ angle of the slip plane centre and centre of gravity of the lamella

$x \quad$ vector variable (decision vector)

$X \quad$ permissible set of solutions $x$

$w_{i} \quad$ relative importance of a criterion, "weight"

$u_{p} \quad$ initial pore pressure before earthquake $\left(\mathrm{kN} / \mathrm{m}^{2}\right)$

$u_{d}$ additional pore pressure due to earthquake $\left(\mathrm{kN} / \mathrm{m}^{2}\right)$

$u \quad$ pore pressure $\left(\mathrm{kN} / \mathrm{m}^{2}\right)$

$u_{k} \quad$ final pore pressure $\left(\mathrm{kN} / \mathrm{m}^{2}\right)$ 
$P_{i}(a, b)$ function of the difference of criterion values of alternatives

$h_{w} \quad$ groundwater level (m)

$C_{Z} \quad$ price of soil for the embankment (euro)

$C_{I} \quad$ price of embankment construction (euro)

$C_{E} \quad$ price of embankment operation (euro)

$c^{\prime} \quad$ effective cohesion $\left(\mathrm{kN} / \mathrm{m}^{2}\right)$

$a_{p} \quad$ earthquake acceleration $\left(\mathrm{m} / \mathrm{s}^{2}\right)$

$N \quad$ earthquake return period

$\gamma_{w} \quad$ volumetric mass density of water $\left(\mathrm{kN} / \mathrm{m}^{3}\right)$

$a_{j} \quad$ variants (selection alternatives)

$A \quad$ finite set of activities

$b_{i} \quad$ breadth of the lamella (m)

$W_{i} \quad$ the weight of the $i^{\text {th }}$ lamella $(\mathrm{kN})$

$\Delta s \quad$ settlement of one layer (m)

$S \quad$ total embankment settlement (m)

$h_{i} \quad$ thickness of embankment layer (m)

$h \quad$ maximum height of design embankment $(\mathrm{m})$

$\Delta \sigma_{v} \quad$ change in stress $\left(\mathrm{kN} / \mathrm{m}^{2}\right)$

$\gamma_{\mathrm{dn}}$ normative unit weight in the dry state, determined by laboratory or field method

$\gamma_{d} \quad$ achieved unit weight in the dry state in the embankment or subsoil bed

$\gamma \quad$ volumetric mass density of the material $\left(\mathrm{kN} / \mathrm{m}^{3}\right)$

$N_{s} \quad$ stability number

$M_{s} \quad$ compressibility modulus $\left(\mathrm{kN} / \mathrm{m}^{2}\right)$

$h_{\max } \quad$ maximum possible height of the embankment with the given characteristics $(\mathrm{m})$

$f_{j i} \quad$ the value of $i^{\text {th }}$ criterion by $j^{\text {th }}$ alternative

$F_{s} \quad$ safety factor

$M \quad$ earthquake magnitude

$R \quad$ distance of the embankment from a fault $(\mathrm{km})$

$\Phi^{+}, \Phi^{-}$positive and negative preference flow

$\Pi(a, b)$ preference index.

\section{References}

[1] Džananović, A. Modern Approach to Evaluating Motorway Routes. Master Thesisis, Author's reprint, University of Tuzla, Tuzla, 2010.

[2] Topbaş, S. A. Karayolu proje elmanlarinin yapim maliyetine etkilerinin incelenmesi. Ph.D. Thesis. Author's reprint, Istanbul, 2006.

[3] Opricović, S.; Hajduković, D. Application of Factor Analysis in Multi-Criteria Optimization. // Symposium Proceedings, Sim-Op-Is 93. / Beograd, 1993, pp. 391-394.

[4] Brans, P.; Mareschal, B.; Vincke, P. PROMETHEE: A new Family of Outranking Methods in MCDM. // Brans, J. P. Ed., Operational Research'84 (IFORS'84) / Amsterdam, 1984, pp. 477-490.

[5] Olgun, M.; Acar, M. H. Investigation of Factors Affecting The Stability of Slopes Subjected to Earthquake Forces. // Selcuk University Journal of the Engineering Science and Technology. 24, 2(2009), pp. 9-37.

[6] Dragašević, Z. Models of Multi-Criteria Analysis for the Ranking of Banks. Ph.D. Thesis. Author's reprint, University of Podgorica, Podgorica, 2010.

[7] Naresh, C.; Edward A. Slope Stability. U.S. Department of Transportation, Federal Highway Administration, Publication No. FHWA NHI-06-088, 2006.

[8] Lukić, D. et al. Criteria for the Installation of the Embankment in the Road Bed, Banja Luka, Bosnia and Herzegovina, 2012.

[9] Samardaković, M. Slope Stability for Arbitrary Slip Surfaces: General and Special Lamella Method Solutions. //
Zbornik radova Građevinsko-arhitektonskog fakulteta Niš. 21, (2009), pp. 77-88.

Authors' addresses

Nazim Manić, MSc, Assistant

State University of Novi Pazar,

Vuka Karadžića bb, 36300, Novi Pazar, Serbia

E-mail: nazimmanić@hotmail.com

Izet Hot, PhD, Assistant

State University of Novi Pazar,

Vuka Karadžića bb, 36300, Novi Pazar, Serbia

E-mail: ihot@np.ac.rs

Dragan Lukić, PhD, Full Profesor

Faculty of Civil Engineering Subotica,

Kozaračka 2a, 24000 Subotica, Serbia

E-mail: lukic@gf.uns.ac.rs

Mladen Pantić, PhD, Full Profesor

State University of Novi Pazar,

Vuka Karadžića bb, 36300, Novi Pazar, Serbia

E-mail: emily983@sbb.rs 